JURNAL RUPA VOL 6 NO 1 AUGUST 2021

DOI address: https://doi.org/10.25124/rupa.v6i1.3737

\title{
Analisis Tanda Dalam Karya Seni Grafis Reza Sastra Wijaya
}

\author{
Mukhlis Patriansah ${ }^{1 *}$, Reza Sastra Wijaya ${ }^{2}$ \\ ${ }^{1}$ Program Studi Desain Komunikasi Visual, Fakultas Ilmu Pemerintahan dan Budaya \\ Universitas Indo Global Mandiri, Palembang, Indonesia \\ ${ }^{2}$ Program Studi Seni Murni, Fakultas Seni Rupa dan Desain, \\ Institut Seni dan Budaya Indonesia Aceh, Aceh, Indonesia
}

\begin{abstract}
Arial 9 Bold)
The form of art is a representation of a reality. In representing this reality, an artist tries to restructure signs or even create new signs. The expression poured into the medium of art is a novelty and has never been formulated at all through existing codes, thus creating a new discourse. With all his abilities, the artist creates new signs in his work by associating an object with another object based on generally accepted rules (conventions). In this study, the author uses Peirce's semiotic theory to analyze the sign system in Reza Sastra Wijaya's graphic art. Contextually, the correlation of the sign system contained in this work with the title of the work, namely "the fraudulent method" and the subject matter or main idea of the case of "bribery" can be interpreted that with "bribes or kickbacks" everything can be achieved and achieved without following the rules. -Rules that apply by convention. This symbolic message is what the artists want to convey through this graphic art work which is associatedwith the game of chess, which is a game of fighting tactics and strategies in achieving a victory. This study aims to provide knowledge to academicians about the study of semiotics, so that they can find out how the sign system is presented in art and design works.
\end{abstract}

\section{Keywords}

printmaking, expression, discourse, symbolic messages, Peircian semiotics 


\title{
Analisis Tanda Dalam Karya Seni Grafis Reza Sastra Wijaya
}

\author{
Mukhsin Patriansah \& Reza Sastra Wiijaya
}

\section{PENDAHULUAN}

Karya seni merupakan sebuah media ekspresi, pemicu utama seorang seniman melahirkan karya seni adalah melalui pengamatan terhadap suatu persoalan atau fenomena yang terjadi di lingkungannya. Fenomena tersebut yang kemudian diekspresikan ke dalam medium seni. Melalui stimulus dan dibekali dengan pengalaman estetis dari siseniman, maka lahirlah karya seni yang memiliki nilai estetis dan juga mengandung makna simbolis. Oleh sebab itu, bentuk suatu karya seni terdiri dari bentuk visual (visual form) dan pesan simbolik yang ingin disampaikan kepada masyarakat luas. Kedua elemen ini menjadi kunci utama dalam melahirkan karya seni, karena karya seni yang baik dapat dilihat dari bagaimana siseniman menyajikan bentuk visual (visual form) dan pesan atau informasi di dalamnya yang disampaikan secara simbolik. Pada prinsipnya bentuk atau wujud suatu karya seni tidak terbentuk dengan sendirinya, hal terpenting yang harus diperhatikan dalam melahirkan karya seni adalah bagaimana menyusun elemen-elemen seni rupa berdasarkan prinsip penyusunan yakni perbedaan (kontras), keselarasan (harmoni), keseimbangan, dan lain sebagainya.

Apabila dilihat berdasarkan konteksnya hal ini sering ditemukan dalam kehidupan seharihari, misalnya antara kaya dan miskin, lelaki dan perempuan, kuat dan lemah dan sebagainya, yang merupakan suatu perbedaan (kontras). Persoalan selanjutnya, bagaimana orang kaya bisa membantu yang miskin, lelaki mampu melindungi perempuan, dan yang kuat mampu merangkul yang lemah. Dengan demikian, terjalin suatu keselarasan (harmoni) dan terciptanya suatu keseimbangan dalam kehidupan. Konsep ini juga senantiasa hadir di dalam penciptaan karya seni karena wujud karya seni di dalamnya selalu menghadirkan suatu perbedaan (kontras), keselarasan (harmoni) dan keseimbangan di dalamnya. Dengan demikian, sebuah karya seni yang lahir memliki nilai estetis yang menjadi daya tarik dalam proses apresiasi seni. Dalam proses apresiasi seni inilah terjadinya suatu interaksi antara penikmat seni dengan karya seni yang ditampilkan.

Selain bentuk visual, pesan dan informasi yang disampaikan secara simbolik juga merupakan bagian terpenting dalam melahirkan karya seni. Karya seni yang baik adalah karya seni yang mampu berkomunikasi dengan masyarakat pendukungnya. Suatu pesan yang dihadirkan tentu harus diperoleh dari sumber informasi yang jelas. Sumber informasi memiliki pengaruh besar terhadap pesan yang disampaikan. Biasanya seorang seniman berusaha menterjemahkan sumber informasi melalui tandatanda visual dan bersifat simbolik. Begitu banyak sumber informasi yang bisa dijadikan gagasan atau ide dalam melahirkan karya seni seperti persoalan-persoalan yang berkaitan dengan isu politik, budaya, sosial, kesehatan, lingkungan, dan lain sebagainya. Persoalan-persoalan inilah yang menjadi dorongan kuat bagi seniman dalam melahirkan karya seni.

Upaya seniman dalam menanggapi suatu fenomena selalu diungkapkan ke dalam karya seni, maka dari itu sebuah karya seni yang lahir merupakan realitas baru yang kompleks, bahkan lebih kompleks dari realitas sesungguhnya. Karena sebuah karya seni di dalamnya berusaha menyajikan fenomenafenomena yang ada di lingkungannya, memiliki makna dan arti tertentu untuk dibedah dan dianalisis (1). Kekuatan terbesar karya seni adalah kekuatan pesan dan makna yang disampaikan secara simbolik kepada penikmat seni atau masyarakat luas. Seorang seniman memiliki kemampuan untuk mengungkapkan suatu fenomena dan menghadirkannya ke dalam karya seni melalui tanda-tanda visual yang memiliki arti dan pemaknaan yang cukup menarik untuk ditelusuri.

Karya seni yang dihadirkan merupakan representasi dari sebuah realitas. Dalam merepresentasikan realitas tersebut seorang seniman selalu menghadirkan sistem tanda di dalam karyanya sebagai wujud kreativitas dan mampu menciptakan kebaruan. Pendekatan yang digunakan seorang seniman dalam 
menyajikan sistem tanda dengan cara mengaitkan suatu objek dengan objek lainnya seperti kesamaan bentuk, karakter dan bahkan kesamaan sifat. Seperti yang diungkapan oleh Marianto di dalam bukunya bahwa kemampuan untuk membuat ungkapan-ungkapan metaforik adalah kekuatan pikiran dan imajinasi manusia dalam menghadirkan gagasan baru, kreatif, atau yang menawarkan kebaruan. Caranya dengan mengaitkan satu objek dengan objek lain, atau satu objek dengan suatu gejala, sehingga dari penggabungan biasosiatif itu muncullah imaji dengan konsep yang unik pula (2).

Selanjutnya, menurut Piliang yang merujuk pendapat Eco menjelaskan bahwa proses komunikasi dapat menciptakan diskursus baru (new discourse), yaitu ketika ekspresi atau isi komunikasi betul-betul baru dan tak terumuskan (undefinable) lewat kode yang ada (3). Penjelasan ini dapat diartikan bahwa karya seni merupakan suatu proses kreatif yang berusaha merestruktur tanda atau bahkan menciptakan tanda-tanda baru, sehingga adanya suatu aturan main (rule) yang baru, dalam hal ini Eco menyebutnya dengan istilah new discourse (diskursus baru). Sebagai contoh misalnya, dalam melahirkan karya seni seorang seniman dituntut untuk menciptakan tatanan baru dalam mengekspresikan suatu persoalan atau fenomena yang tengah terjadi, dari sinilah seorang seniman mengerahkan segala kemampuannya untuk melahirkan tanda-tanda baru atau merestruktur tanda yang sudah ada dengan melihat korelasi secara umum (konvensi). Seperti penjelasan Eco dalam Pilliang bahwa penggunaan fungsi tanda diatur oleh sebuah kode, ia harus mengusulkan cara baru pengkodean (new coding). Untuk mengusulkan sebuah kode, berarti mengusulkan korelasi, dan setiap korelasi harus berdasarkan sebuah konvensi (convention). Akan tetapi, oleh karena konvensi itu sendiri belum ada, maka ia harus melandasi korelasi tersebut berdasarkan konvensi baru (new convention) (3).

Kehidupan intelektual dan sosial manusia didasarkan pada penghasilan, penggunaan, dan pertukaran tanda, misalnya saat kita membuat isyarat, berbicara, menulis, membaca, menonton acara televisi, mendengarkan musik, melihat sebuah lukisan, kita tengah melakukan penggunaan dan penafsiran tanda (4). Penafsiran tanda dalam sebuah karya seni memungkinkan kita sebagai apresiator dapat dengan mudah untuk memahami makna yang ingin disampaikan oleh sisenimannya melalui analisis semiotika yang digunakan nantinya (1). Ketika melihat sebuah tanda yang dihadirkan dalam wujud karya seni, kita selalu berusaha menginterpretasikan tanda tersebut. Interpretasi dilakukan dengan cara melihat relasirelasi yang ada dengan suatu realitas.

Proses interpretasi dapat diperoleh dari suatu pengetahuan yang merupakan buah dari pengalaman kita terhadap berbagai hal yang terjadi di dunia ini. Suatu pengalaman timbul karena sesuatu tersebut pernah kita lihat dan kita alami. Dalam konteks tertentu, suatu pengalaman bisa diperoleh dari pembelajaran terhadap lingkungan dan budaya atau kultural. Sebagai contoh misalnya, ketika seseorang yang berasal dari kota besar pergi dan menginap di suatu daerah yang berada di pedesaan yang sangat kental dengan adat-istiadatnya, maka orang tersebut harus mempelajari apa-apa saja yang tidak boleh dilakukan di desa tersebut. Dari sini kita sudah melakukan proses interpretasi dengan melihat prilakuprilaku masyarakat pedesaan, mulai dari sistem kekerabatan, gotong royong, upacara tradisional, upacara kematian, pernikahan dan lain sebagainya, yang sama sekali berbeda dengan kehidupan di kotakota besar pada umumnya.

Dalam penelitian ini penulis menggunakan analisis interpretasi tanda dalam karya seni grafis Reza Sastra Wijaya yang berjudul "Cara Curang". Tema pokok karya ini adalah tentang "suap" yang masih banyak ditemukan di Negeri ini. Konsep visual karya ini menggunakan permainan catur yang merupakan permainan adu taktik dan strategi, namun dalam penyajiannya ada diskursus baru (new discourse) yang dihadirkan oleh seorang Reza di dalam karyanya. Karya ini sudah dipamerkan di lobi gedung Hoerijah Adam dalam pameran Tugas Akhir mahasiswa jurusan Seni Murni Institut Seni Indonesia Padangpanjang. Bentuk visual yang ditampilkan dalam karya ini cukup mencuri perhatian penulis karena digarap sebaik mungkin dan dapat dijadikan acuan dalam perkembangan seni grafis di Sumatera, khususnya dalam dunia akademik Institut Seni Indonesia Padangpanjang. Di sisi lain, si seniman sangat memperhatikan aspek-aspek prinsip penyusunan rupa dalam melahirkan karya ini, sehingga membentuk satu kesatuan yang utuh (unity). Pesan simbolik yang terkandung di dalam karya ini cukup menarik untuk di telusuri, melalui karya ini si seniman mencoba memberikan kritikan dengan harapan mampu mengubah tatanan baru yang lebih baik untuk negeri ini. Melalui penelitian ini, diharapkan bisa memberikan pengetahuan kepada para insan akademisi terhadap kajian ilmu semiotika, sehingga mereka bisa mengetahui bagaimana sistem tanda yang dihadirkan dalam karya seni rupa dan desain. Semiotika adalah sebuah cabang keilmuan yang memperlihatkan pengaruh semakin penting sejak empat dekade yang lalu, tidak saja sebagai metode kajian (decoding), akan tetapi juga sebagai metode penciptaan (encoding) (3). Di samping itu, kajian yang dilakukan dalam penelitian ini berfokus pada sistem tanda yang digunakan dalam karya seni grafis Reza Sastra dan mengetahui bagaimana sistem tanda tersebut diaplikasikan dan berkerja sesuai dengan kapasitas serta latar belakang budaya yang berbeda. Dalam penelitian ini 
penulis menggunakan pendekatan teori semiotika yang diusung oleh Charles Sanders Peirce. Secara teoritis tanda yang dikemukakan oleh Peirce terdiri dari tiga unsur yang disebut dengan istilah triadik atau triangle. Menurut Piliang model triadik Peirce ini memperlihatkan tiga elemen utama pembentuk tanda, yaitu representamen (sesuatu yang mempresentasikan sesuatu yang lain), objek (sesuatu yang dipresentasikan) dan interpretan (interpretasi seseorang tentang tanda) (3). Batasan teori yang digunakan dalam penelitian ini adalah tanda berdasarkan objek yang terdiri dari icon (kemiripan), indeks (sebab akibat), dan simbol (konvensi). Di sisi lain, pembatasan teori ini dilakukan untuk mempermudah penulis dalam menganalisis dan menghindari kesalahpahaman dalam membaca tulisan ini.

\section{METODE PENELITIAN}

Pada prinsipnya, pendekatan semiotika sebagai metode penelitian memiliki dua tahapan. Pertama, analisis tanda secara individual, misalnya jenis tanda, mekanisme atau struktur tanda, dan makna tanda secara individual. Kedua, analisis tanda sebagai sebuah kelompok atau kombinasi, yaitu kumpulan tanda-tanda yang membentuk apa yang disebut sebagai teks (text) (3). Selanjutnya Piliang yang merujuk pendapat Twhwaites menjelaskan bahwa teks dalam pengertiannya yang paling sederhana adalah kombinasi tanda-tanda (3).

Di samping itu, penelitian ini juga menggunakan metode penelitian kualitatif. Pada prinsipnya penelitian kualitatif bersifat tafsiran berdasarkan identifikasi data yang telah dikumpulkan melalui proses observasi dan wawancara. Proses observasi dan wawancara yang dilakukan, guna mengetahui gambaran umum mengenai konsep penciptaan karya seni, sehingga interpretasi terhadap sistem tanda yang dilakukan memiliki validitas yang akurat dan bersifat objektif. Penggunaan metode kualitatif dalam penelitian ini terdiri dari tiga tahapan yakni pertama, tahapan deskripsi lebih bersifat menguraikan, kedua proses analisis merupakan korelasi antara data dan fakta yang ditemukan, dan ketiga tahapan interpretasi merupakan proses penafsiran.

Pada tahapan deskripsi langkah-langkah yang dilakukan adalah menguraikan dan membedah secara detail unsur-unsur yang ada di dalam karya seni grafis Reza Sastra Wijaya mulai dari warna, garis, tekstur, ruang, bentuk dan teknik, media, gaya atau aliran yang digunakan dan lain sebagainya, yang membentuk satu kesatuan (Unity). Pada tahapan kedua, langkah-langkah yang dilakukan adalah mengkorelasikan antara unsur-unsur yang telah diuraikan dengan fakta dan data yang ditemukan meliputi latar belakang siseniman, keragaman budaya, prilaku sosial serta pengalaman estetis yang memicu dan mendorong si seniman untuk melahirkan karya seni grafis ini, langkah-langkah yang dilakukan dalam tahapan terakhir yakni proses interpretasi adalah menafsirkan suatu objek penelitian berupa karya seni grafis Reza sastra Wijaya yang merupakan representasi dari sebuah realitas yang dialaminya dengan tujuan untuk mengubah tatanan baru yang lebih baik untuk bangsa ini.

\section{STRUKTUR TRIADIK DAN SEMIOSIS TANDA MENURUT PEIRCE}

Charles Sanders Peirce seorang ahli filsuf dari Amerika (1839-1914) mengutarakan bahwa kehidupan manusia dicirikan oleh pencampuran tanda dan cara penggunaannya dalam aktivitas yang bersifat representatif (4). Tanda dapat diartikan sebagai sesuatu yang dipinjam, dipakai dan digunakan untuk memaknai sesuatu yang lain. Dengan demikian, sebuah tanda memerlukan idiom lain dan bersifat representatif, dalam konteksnya tanda tidak bisa mewakili dirinya sendiri dalam situasi apapun. Representatif di sini dapat diartikan sebagai makna dari sebuah tanda yang memiliki korelasi terhadap realitas berdasarkan aturan main (rule) dari latar belakang budaya yang beragam. Karya seni sebagai bahasa (teks) visual tentu tidak dapat dipisahkan berdasarkan kontekstual di mana karya seni tersebut dilahirkan, hal ini dikarenakan ada suatu relasi yang dibangun dari sebuah tanda terhadap realitas. Realitas yang dihadirkan dalam karya seni merupakan wujud dari kreativitas dan kebaruan yang memiliki aturan main (rule) berdasarkan suatu konvensi atau bahkan menciptakan konvensi baru.

Tanda bagi Peirce merupakan sesuatu bagi seseorang mewakili sesuatu yang lain dalam beberapa hal atau kapasitas tertentu (5). Peirce melihat tanda (representamen) sebagai bagian yang tidak terpisahkan dari objek referensinya serta pemahaman subjek atas tanda (interpretan) (3). Menurut Noth dalam Pilliang menjelaskan bahwa Peirce melihat subjek sebagai bagian yang tidak dapat dipisahkan dari proses signifikasi. Model triadik Peirce (representamen + object + interpretan = tanda) memperlihatkan peran besar subjek dalam proses transformasi bahasa. Tanda dalam pandangan Peirce selalu berada di dalam proses perubahan tanpa henti, yang disebut proses semiosis tak berbatas (unlimited semiosis), yaitu proses penciptaan rangkaian interpretan yang tanpa akhir (3). Bagi Peirce tanda dan pemaknaannya bukan struktur melainkan suatu proses kognitif yang disebut dengan semiosis. Jadi, semiosis adalah proses pemaknaan dan penafsiran tanda (6). Untuk lebih jelas lihat gambar di bawah ini : 


\section{Interpretan}

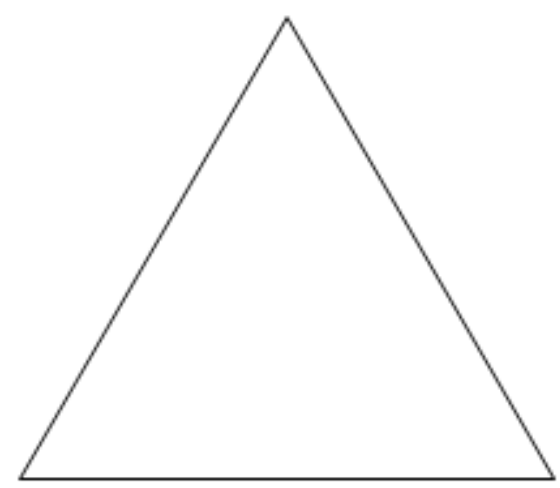

Gambar 1. Kerangka Pikiran

Peirce

Representamen

Objek

Seperti yang sudah dijelaskan sebelumnya, struktur tanda yang ditawarkan oleh Peirce dikenal dengan istilah triadik atau triangle. Struktur tanda ini dapat dilihat dari tipologi tanda yang dikonsepkan oleh Peirce yang terdiri dari tanda representamen merupakan sistem tanda yang merepresentasikan sesuatu yang lain, object merupakan sesuatu yang direpresentasikan, sedangkan interpretan merupakan penafsiran tanda. Konsep triadik yang dikemukakan oleh Peirce memiliki relasi antara representamen, object dan interpretan. Struktur triadik ini yang disebut peirce sebagai proses semiosis yang merupakan korelasi tanda dengan realitas yang direpresentasikan. Contohnya, ketika seorang seniman melihat fenomena para oknum pejabat yang melakukan tindakan koruptor, hal ini merupakan bagian dari "representamen" yang kemudian dikaitkan dan diterjemahkan melalui "object' yakni binatang "babi" dengan tampilan visual mengenakan jas dan berdasi, selanjutnya proses penafsiran objek yang disebut dengan "interpretan" dapat dimaknai sebagai keserakahan. Proses interpretasi terhadap objek tersebut memungkinkan lahirnya tanda baru yang merepresentasikan sesuatu yang lain dan bersifat kebaruan. Maka dari itu, semiosis tanda yang dikemukakan oleh Peirce merupakan semiosis tanda yang tidak berkesudahan atau tanpa batas. Konsep tanda yang dikemukakan oleh Peirce memiliki uraian yang lebih detail dan lebih lengkap, untuk lebih jelasnya lihat tabel tipologi tanda Peirce di bawah ini :

Tabel 1. Tipologi tanda Peirce (3)

\begin{tabular}{|c|c|c|c|c|}
\hline \multirow{2}{*}{\multicolumn{2}{|c|}{$\begin{array}{l}\text { Tanda } \\
\text { Representamen }\end{array}$}} & \multicolumn{3}{|l|}{ Trikotomi } \\
\hline & & \multirow{2}{*}{$\begin{array}{l}\text { Object } \\
\text { Qualisign } \\
\text { (kualitas tanda yang } \\
\text { bersifat apa adanya) }\end{array}$} & \multirow{2}{*}{$\begin{array}{l}\text { Interpretan } \\
\text { Icon } \\
\text { (tanda berdasarkan } \\
\text { tiruan atau } \\
\text { kemiripan) }\end{array}$} & \multirow[b]{2}{*}{$\begin{array}{l}\text { Rheme } \\
\text { (tanda yang } \\
\text { interpretasinya masih } \\
\text { bersifat kemungkinan) }\end{array}$} \\
\hline \multirow{3}{*}{ Kategori } & $\begin{array}{l}\text { Firstness } \\
\text { Otonom. }\end{array}$ & & & \\
\hline & $\begin{array}{l}\text { secondness } \\
\text { dihubungkan } \\
\text { dengan realitas. }\end{array}$ & $\begin{array}{l}\text { Sinsign } \\
\text { (Tanda berdasarkan } \\
\text { pengalaman, prilaku } \\
\text { dan perbandingan) }\end{array}$ & $\begin{array}{l}\text { Indeks } \\
\text { (tanda berdasarkan } \\
\text { kausal atau sebab } \\
\text { akibat) }\end{array}$ & $\begin{array}{l}\text { Dicent } \\
\text { (interpretasi tanda } \\
\text { berdasarkan eksistensi } \\
\text { aktual) }\end{array}$ \\
\hline & $\begin{array}{l}\text { Thirdness } \\
\text { Dihubungkan } \\
\text { dengan aturan, } \\
\text { konvensi atau } \\
\text { kode. }\end{array}$ & $\begin{array}{l}\text { Legisign } \\
\text { (sintesis dari tipe } \\
\text { tanda berdasarkan } \\
\text { aturan yang berlaku) }\end{array}$ & $\begin{array}{l}\text { Symbol } \\
\text { (tanda berdasarkan } \\
\text { konvensi atau } \\
\text { kesepakatan) }\end{array}$ & $\begin{array}{l}\text { Argument } \\
\text { (tanda yang sudah } \\
\text { diinterpretasikan } \\
\text { berdasarkan aturan dan } \\
\text { konvensi }\end{array}$ \\
\hline
\end{tabular}

Berdasarkan tabel ini dapat diartikan bahwa proses semiosis tanda, baik tanda representamen, object dan interpretan dimulai dengan tanda pertama (Firstness) yang bersifat otonom atau berdiri sendiri, tanda kedua (secondness) merupakan proses tanda berdasarkan hubungannya dengan realitas, sedangkan tanda ketiga (thirdness) selalu berkaitan dengan aturan konvensi. Dalam penelitian ini, penulis berfokus pada teori semiotika Peirce dengan batasan tanda sebagai objek yang terdiri dari icon, indeks, dan symbol. Dalam sistem simbolik, semua tanda memiliki pemaknaan yang didasari oleh kesepakatan 
bersama (konvensi), dengan demikian sebuah tanda harus dilihat berdasarkan konteks kebudayaan suatu masyarakat atau komunitas tertentu. Hal ini dikarenakan sebuah tanda yang dihadirkan memiliki penafsiran dan tanggapan dari masyarakat penggunanya. Seekor binatang "babi" misalnya, digunakan sebagai tanda yang merepresentasikan seorang oknum koruptor, sistem tanda ini hanya berlaku di negara Indonesia, hal ini dikarenakan dari beberapa kasus banyak ditemukan para oknum pejabat yang melakukan tindakan koruptor dan sudah menjadi suatu kebudayaan bagi bangsa Indonesia. Pemaknaan ini belum tentu berlaku bagi negara lain yang memiliki kultur dan budaya yang berbeda.

Memaknai sebuah tanda bagi peirce tidak terlepas dari kapasitas tanda yang dihadirkan dan memiliki korelasi terhadap realitas. Dalam situasi apapun kehadiran dan penggunaan sebuah tanda harus benarbenar bisa merepresentasikan suatu realitas berdasarkan kultur budaya masyarakat yang beragam. Tanda berdasarkan object tentu memiliki aturan dalam proses kognitifnya, dimulai dari icon tanda berdasarkan kemiripan, indeks tanda berdasarkan sebab akibat dan symbol tanda berdasarkan aturan konvensi. Rangkaian proses ini dapat dilihat dari penggunanan tanda visual "babi" yang mengenakan jas dan berdasi sebagai simbol koruptor. Apabila dilihat secara fisik, binatang babi dan koruptor sangat berbeda dan tidak ada manusia yang mau disamakan dengan binatang babi, akan tetapi keduanya memiliki kesamaan dari sisi sifat dan prilaku yakni sama-sama rakus, sifat dan prilaku binatang babi dan koruptor di sini merupakan bagian dari icon (kemiripan). Selanjutnya, tanda bersifat kausal atau indeks dapat dilihat dari sebab akibat sebuah tanda yang digunakan untuk merepresentasikan sesuatu yang lain, contoh yang sangat sederhana adalah "ada asap pasti ada api". Asap di sini merupakan sebuah tanda yang merepresentasikan bahwa dibalik asap pasti ada api di dalamnya. Begitu juga dengan penggunaan tanda visual bintang "babi" dapat dilihat secara kausal berdasarkan sebab akibat. Bagi petani binatang babi merupakan hama yang bisa merusak tanaman mereka, dengan kerakusannya binatang babi melahap dan memakan bahkan bisa merusak tanaman mereka. Begitu juga dengan kondisi bangsa ini yang banyak diisi oleh para oknum-oknum koruptor yang mampu merusak tatanan bangsa dan menyengsarakan rakyat jelata. Berdasarkan icon dan indeks tersebut binatang babi merupakan symbol dari para oknum koruptor yang sudah menjadi budaya bagi bangsa ini.

\section{MEMBACA STRUKTUR TANDA DALAM KARYA SENI}

Karya seni merupakan suatu proses kreatif yang mengandalkan kemampuan (skill) yang dimiliki sisenimannya. Seperti yang diungkapkan Jakob Sumardjo dalam bukunya bahwa sebuah karya seni juga sangat membutuhkan aktivitas kreatif dari siseniman sehingga karya yang dilahirkan nantinya merupakan karya yang kreatif, inofativ, dan mempunyai nilai orisinalitas (7). Selanjutnya Sudarmaji menjelaskan dalam bukunya bahwa suatu hasil seni yang baik bukanlah suatu manifestasi sembarangan, mencipta asal jadi. Suatu karya seni dilahirkan karena dorongan menyeluruh, kuat dan banyak segi (8). Kemampuan yang paling mendasar dan bersifat fundamental adalah bagaimana seorang seniman mampu menguasai alat dan bahan yang digunakan dalam melahirkan karya seni. Tanpa penguasaan alat dan bahan yang baik tentu seorang seniman tidak mampu merefleksikan gagasan atau idenya ke dalam medium seni. Di samping itu, proses apresiasi seni juga merupakan bagian terpenting dalam melahirkan karya seni, hal ini dapat dilakukan dengan cara melihat dan mengamati objek-objek karya estetis salah satunya melalui event pameran. Secara keseluruhan proses kreatif dan apresiasi seni merupakan bagian dari pengalaman estetis. Rentetan proses yang panjang dalam melahirkan sebuah karya seni menjadikan wujud dari sebuah karya seni merupakan wujud yang kompleks, bahkan lebih kompleks dari realitas yang sebenarnya.

Bentuk adalah hal pertama yang dapat dilihat oleh pengamat karena di dalamnya terdapat unsurunsur elemen visual seperti garis, shape, value, tekstur, warna dan ruang. Bentuk dianggap sebagai suatu yang fundamental, berdiri sendiri sebagai suatu elemen tertutup dan terstruktur dalam dunia visual (9). Membaca struktur tanda dalam karya seni tidak terlepas dari proses pembedahan terhadap kombinasi tanda yang disusun membentuk sebuah teks visual. Proses pembedahan struktur tanda yang membentuk teks visual tersebut merupakan bagian dari aktivitas deskripsi. Deskripsi berasal dari bahasa inggris describe dan bahasa latin describere yang artinya memaparkan, menguraikan atau menggambarkan. vDengan demikian, deskripsi dapat diartikan sebagai suatu proses penggambaran representasi verbal dari sebuah objek yang diamati. Tujuan utama dari kegiatan deskripsi adalah mengidentifikasi dan menguraikan data yang dihasilkan dari observasi dan wawancara terhadap objek penelitian untuk mempermudah proses analisis dan interpretasi.

Membaca struktur tanda dalam karya di atas dapat dilakukan dengan cara deskripsi. Deskripsi merupakan proses kegiatan yang sangat penting dan bersifat fundamental dalam menganalisis suatu objek penelitian, dalam hal ini adalah karya seni. Dalam praktiknya proses deskripsi tidak boleh diabaikan karena sangat berpengaruh terhadap proses analisis, evaluasi dan penilaian. Kegiatan deskripsi dapat 
dilakukan dengan cara membedah unsur-unsur yang ditangkap dari tampilan visual sebuah karya seni. Dalam proses analisis semiotika, kegiatan deskripsi sangat membantu untuk mengidentifikasi sistem tanda yang ada di dalam karya seni. Sistem tanda yang diidentifikasi meliputi tanda berdasarkan object yakni, icon, indeks dan symbol. Struktur tanda yang akan dibedah dalam penelitian ini adalah struktur tanda yang terdapat di dalam karya seni grafis Reza Sastra Wijaya.

Gambar 2. "Cara Curang”, Reza Sastra Wijaya, $80 \times 120$

Relief print, serigraphy on canvas, 2012

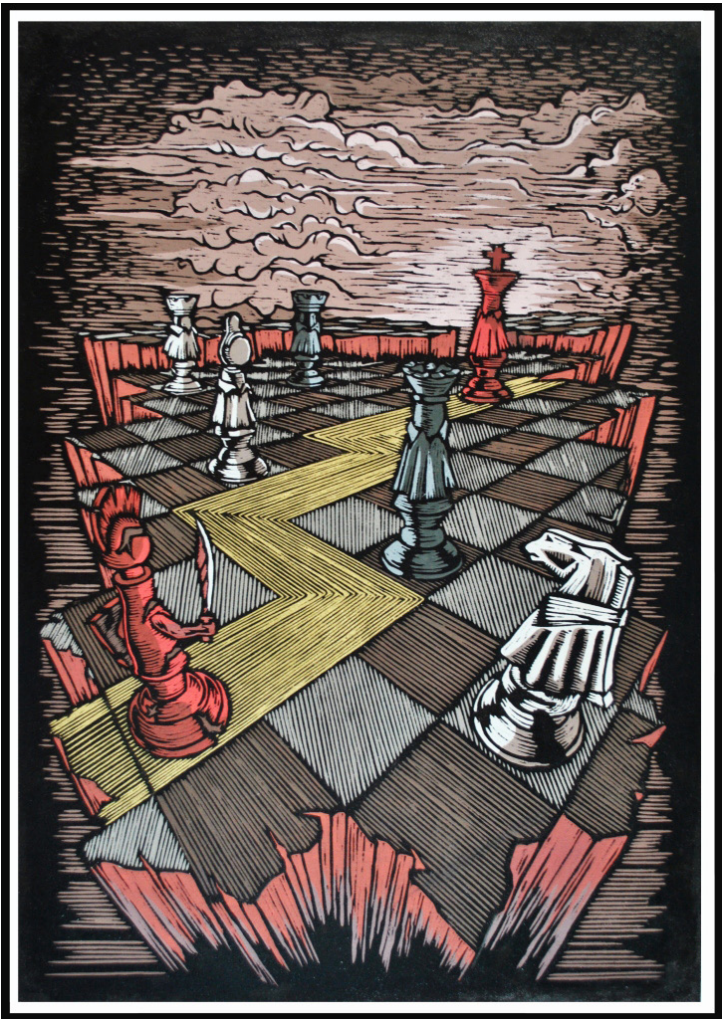

Karya seni yang diulas merupakan karya seni grafis yang dibuat dengan menggunakan teknik cetak cukil hardboard dan dicetak dengan menggunakan metode serigrafi di atas kanvas dengan ukuran 80 x $120 \mathrm{~cm}$ yang dibuat pada tahun 2012. Tampilan visual pada karya di atas di tampilkan dengan posisi portrait. Karya seni grafis ini berjudul "cara curang" dengan subject matter atau tema pokok karya yakni tentang kasus "suap". Elemen-elemen yang disusun berdasarkan prinsip penyusunan yang membentuk suatu kesatuan (unity), hal ini dapat dilihat dari unsur warna, garis, irama, bentuk (form), bidang (shape), tekstur dan lain sebagainya. Adapun unsur warna yang digunakan dalam karya ini adalah warna merah, kuning keemasan, hitam, putih, abu-abu dan soft cream. Bentuk yang ada di dalam karya ini dihasilkan dari proses pencukilan yang menghasilkan garis horizontal, garis vertikal dan garis lengkung, setiap pertemuan garis tersebut membentuk sebuah papan permainan catur dan buah catur serta bentuk awan sebagai background dari karya ini.

Selanjutnya, buah catur yang ditampilkan dalam karya ini terdiri dari raja, menteri, gajah, kuda, dan benteng, namun tidak terdapat bidak atau pion di dalamnya. Raja dan gajah menggunakan warna merah, sedangkan kuda, gajah dan benteng menggunakan warna putih, untuk menteri dan benteng menggunakan warna abu-abu. Susunan buah catur yang ada di dalam karya ini juga sangat menarik, dengan mempertimbangakan segala aspek prinsip penyusunan. Kuda yang berwarna putih dan gajah berwarna merah dengan menggunakan pedang ditempatkan pada bagian depan karya, menteri yang berwarna abu-abu dan gajah yang berwarna putih berada dibagian tengah sedangkan dua benteng yang berwarna abu-abu dan putih ditempatkan pada bagian belakang sejajar dengan posisi raja yang berwarna merah. Pada bagian papan catur terdapat perpaduan unsur garis yang membentuk sebuah bidang zigzag dengan menggunakan warna kuning keemasan. Di dalam bidang zigzag yang berwarna kuning keemasan tersebut terdapat buah catur gajah yang membawa sebuah pedang dengan pandangan mengarah kepada sang raja. Tampilan papan permainan catur yang ada di dalam karya ini digambarkan seperti papan permainan catur pada umumnya, yang terdiri dari warna hitam dan putih. Apabila diperhatikan dengan seksama, papan permainan catur dalam karya ini seolah-olah digambarkan terpisah menjadi tiga bagian. Papan catur bagian pertama yang menjadi pusat perhatian (center of interest), sedangkan dua bagiannya lagi terdapat di bagian belakang. Papan permainan catur 
dalam karya ini digambarkan seolah-olah seperti tebing yang curam. Warna yang ada pada bagian tebing yang curam tersebut adalah warna merah, putih dan hitam, sedangkan warna yang digunakan pada bagian pinggir dari karya ini menggunakan warna hitam dan putih.

Komposisi yang terdapat dalam karya ini merupakan hasil perpaduan dari unsur-unsur rupa yang disusun berdasarkan prinsip penyusunan. Secara keseluruhan, komposisi yang ada dalam karya ini sangat ideal, hal ini dapat dilihat dari keseimbangan dan proporsi yang digunakan. Keseimbangan dan proporsi baik dari segi bentuk, warna, pencahayaan disusun sebaik mungkin yang membuat karya ini menjadi menarik dan seolah-olah hidup. Di samping keseimbangan dan proporsi, dalam karya ini juga terdapat prinsip perlawanan atau perbedaan (kontras) hal ini dapat dilihat dari penggunaan warna kuning keemasan pada bagian papan permainan catur. Selanjutnya, perspektif ruang menjadi prioritas utama siseniman dalam melahirkan karya ini. Bentuk gumpalan awan yang ada di dalam karya ini terbentuk dari perpaduan antara garis lengkung dan garis lurus dengan menggunakan warna soft cream. Satu hal yang menjadi sorotan dari karya ini adalah tidak terdapat bayangan di setiap buah catur yang ditampilkan.

\section{ANALISIS TANDA MENGGUNAKAN SEMIOTIKA PEIRCE}

Menyingkap makna dalam karya seni dapat dilakukan melalui proses analisis dengan cara mengkorelasikan struktur tanda secara faktual. Uraian yang telah dijabarkan dalam proses deskripsi dapat dijadikan titik balik untuk membaca struktur tanda dan mengungkapkan makna di balik tanda yang dihadirkan dalam karya seni. Secara metodologi analisis merupakan lanjutan dari tahapan deskripsi. Menurut Marianto analisis adalah pengujian atas sesuatu yang secara keseluruhan kompleks, dengan cara memecah-mecahnya jadi bagian per bagian, dan mengobservasinya satu per satu (2). Pengujian di sini dapat diartikan sebagai suatu kegiatan yang dilakukan dengan melihat relasi setiap elemen-elemen secara keseluruhan seperti garis, warna, bentuk, ruang, tekstur dan lainnya. Selanjutnya, elemenelemen tersebut dihubungkan dengan judul karya dan materi subjek atau gagasan pokok sebuah karya seni. Melalui kegiatan analisis ini dapat dijadikan landasan dalam tahapan interpretasi tanda, sehingga hasil interpretasi yang dilakukan lebih valid dan tentunya lebih bersifat objektif. Proses analisis tanda berdasarkan teori semiotika Peirce dengan batasan tanda berdasarkan object yang terdiri dari icon, indeks, dan symbol yang dilakukan dapat dilihat pada uraian di bawah ini :

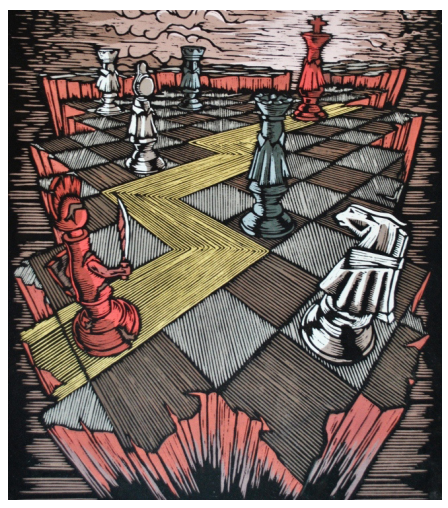

Gambar 3. Detail karya

Icon yang terdapat pada sign terdiri dari tiga papan permainan catur, pada bagian depan, terdapat papan permainan catur lengkap dengan buah catur yang terdiri dari Raja, Menteri, Gajah, Kuda, dan Benteng, khusus untuk Raja \& Gajah yang berwarna merah terdapat bidang yang berbentuk zigzag dengan warna kuning keemasan. Di samping itu, gajah yang berwarna merah dalam karya ini menggenggam sebuah pedang ditangannya. Index dapat dilihat dari penggunaan papan permainan catur yang ada di dalam karya ini secara kausal merupakan wilayah kekuasaan. Dalam sistem perperangan kolosal peranan raja, menteri, gajah, kuda, dan benteng merupakan elemen penting dalam meraih kemenangan, dalam permainan catur juga demikian buah catur yang terdapat di dalam karya ini memiliki peranan penting sebagai panglima tertinggi dalam sebuah pertempuran. Pola zigzag dalam karya ini merupakan sebuah pola yang tidak beraturan, sedangkan warna kuning keemasan apabila dihubungkan dengan realitas merupakan warna kejayaan, kemenangan dan kegemilangan. Symbol, secara konvensional permainan catur merupakan permainan adu taktik dan strategi. Dalam permainan ini setiap buah catur memiliki gerakan dan langkah sesuai dengan aturan yang berlaku secara umum (konvensi), tetapi tidak dengan gajah berwarna merah yang membawa pedang memiliki gerakan yang tidak beraturan yakni zigzag dengan warna kuning keemasan sebagai simbol kemenangan. Pedang secara konvensional merupakan senjata yang digunakan dalam perperangan yang berfungsi untuk membunuh lawan atau musuh. Sedangkan raja merupakan kunci dalam permainan ini, jika raja mati maka permainan selesai. Warna merah secara umum dapat diartikan sebagai alarm atau tanda bahaya. 
Icon berupa raja berwarna merah. Index dapat dilihat berdasarkan kausal bahwa raja merupakan pemimpin tertinggi dalam sistem kerajaan, sedangkan symbol, secara konvensional bahwa dalam permainan catur raja menjadi kunci permainan, jika raja mati maka permainan selesai. Gerak dan langkah raja bebas kearah mana saja baik ke depan, belakang, diagonal, ke kiri dan ke kanan. Namun demikian, raja hanya bisa melangkah sebanyak satu kotak saja.

Icon berupa gajah berwarna merah dengan membawa pedang ditangannya. Index Pasukan bergajah dalam perperangan kolosal merupakan garda terdepan yang menjadi kunci untuk memenangkan pertempuran. Sedangkan symbol, dalam permainan catur gerak dan langkah gajah memiliki aturan secara konvensional yakni hanya bisa melangkah secara diagonal, tetapi tidak bisa melangkahi bidak catur lainnya.

Icon berupa menteri yang berwarna abu-abu. Index dapat dilihat secara kausal bahwa menteri dalam sistem kerajaan merupakan pendamping dari raja. Oleh sebab itu, menteri bisa dikatakan sebagai tangan kanan raja yang menentukan suatu kebijakan dan keputusan yang akan ditetapkan. Sedangkan symbo dapat diartikan secara konvensional bahwa menteri dalam permainan catur memiliki ruang gerak yang pleksibel yakni bisa bergerak ke semua arah, akan tetapi tidak bisa melompati bidak lain. Dengan pergerakannya yang fleksibel menjadikan menteri dalam permainan catur sebagai daya gedor untuk mengalahkan musuh.

Icon berupa gajah berwarna putih, index dapat dilihat secara kausal bahwa pasukan bergajah dalam perperangan kolosal merupakan garda terdepan yang menjadi kunci untuk memenangkan pertempuran. Sedangkan symbol dapat diartikan bahwa dalam permainan catur gerak dan langkah gajah memiliki aturan secara konvensional yakni hanya bisa melangkah secara diagonal, tetapi tidak bisa melangkahi bidak catur lainnya.

Icon berupa Benteng berwarna putih dan abu-abu, index dapat dilihat secara kausal bahwa Benteng merupakan tempat berlindung raja dan rakyatnya dari serangan musuh. Jika suatu kerajaan memiliki benteng yang kokoh, tentu kerajaan tersebut merupakan kerajaan yang besar. Sedangkan symbol, dalam permaianan catur benteng memiliki peranan penting sebagai pelindung dan juga sebagai penyerang. Secara konvensional gerak dan langkah benteng hanya bisa berjalan lurus ke depan, bawah, ke kiri dan ke kanan, akan tetapi tidak bisa melangkahi bidak yang lain.

Icon berupa Kuda berwarna putih, index dapat dilihat secara kausal bahwa dalam perperangan pasukan berkuda memiliki peranan penting dalam meraih kemenangan. Oleh sebab itu, jika suatu kerajaan memiliki pasukan berkuda yang banyak maka dengan mudah mereka bisa memenangkan suatu pertempuran. Sedangkan index, dalam perperangan pasukan berkuda memiliki peranan penting dalam meraih kemenangan. Oleh sebab itu, jika suatu kerajaan memiliki pasukan berkuda yang banyak maka dengan mudah mereka bisa memenangkan suatu pertempuran.

Icon berupa gumpalan awan yang berwarna soft crea, index dapat dilihat secara kausal bahwa gumpalan awan yang tebal menyelimuti langit akan memberikan suasana mencekam akan terjadinya suatu badai hujan yang lebat. Sedangkan symbol, gumpalan awan yang tebal menyelimuti langit akan memberikan suasana mencekam akan terjadinya suatu badai hujan yang lebat.

Berdasarkan hasil analisis tanda berdasarkan object yang terdiri dari icon, indeks, dan symbol yang telah dilakukan, maka dapat di tarik benang merah dari fakta-fakta yang telah diungkapkan. Proses analisis struktur tanda yang telah dilakukan menjadi pegangan untuk menelusuri makna simbolik berdasarkan suatu aturan yang berlaku secara umum atau konvensi. Dalam semiotika Peirce sebuah simbol merupakan tanda pada tingkat ketiga (thirdness), yang hadir karena ada suatu kemiripan (icon) yakni tanda pada tingkat pertama (Firstness) dan sebab akibat (indeks) yakni tanda pada tingkat kedua (secondness). Simbol-simbol yang dihadirkan dalam karya ini memiliki relasi dengan gagasan pokok atau materi subjek yakni tentang kasus "suap" dengan judul karya yakni "cara curang". Tampilan sebuah karya seni tidak hanya sekedar persoalan menyusun elemen-elemen rupa berdasarkan prinsip penyusunan, akan tetapi persoalan lain yang jauh lebih penting adalah bagaimana pesan simbolik yang ingin disampaikan siseniman melalui karyanya berdasarkan suatu fenomena yang menjadi latar belakang lahirnya karya seni.

\section{INTERPRETASI MAKNA DI BALIK TANDA'}

Interpretasi merupakan suatu penafsiran terhadap objek penelitian, dalam hal ini adalah karya seni. Secara representatif struktur tanda yang dihadirkan dalam karya seni memiliki pemaknaan secara simbolik. Dalam pemakaian sehari-hari, kata makna digunakan dalam berbagai bidang maupun konteks pembicaraan (10). Pernyataan ini menjelaskan bahwa makna dapat disejajarkan dengan arti dan 
maksud tertentu yang ingin disampaikan. Struktur tanda yang ada dalam karya seni grafis ini mencoba melahirkan diskursus baru dengan mengaitkan satu objek dengan objek lainnya. Ekspresi yang dituangkan ke dalam medium seni merupakan suatu kebaruan dan belum pernah terumuskan sama sekali melalui kode-kode yang ada. Dengan segala kemampuannya siseniman melahirkan tanda-tanda baru di dalam karyanya dengan cara mengaitkan suatu objek dengan objek lainnya berdasarkan suatu aturan yang berlaku secara umum (konvensi).

Tabel 1. Hasil Interpretasi tanda dan makna dalam karya seni grafis Reza Sastra Wijaya

\begin{tabular}{|c|c|c|c|}
\hline Tanda & Icon & Index & Symbol \\
\hline 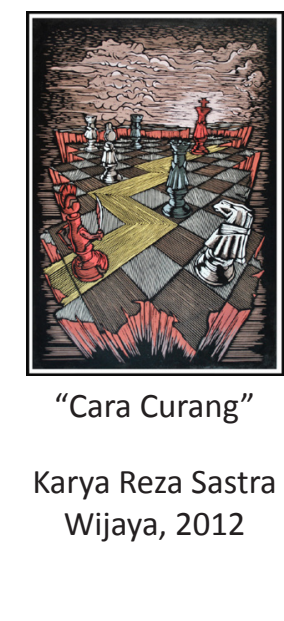 & $\begin{array}{l}\text { Tiga papan } \\
\text { permainan catur } \\
\text { lengkap dengan } \\
\text { buah catur yang } \\
\text { terdiri dari raja, } \\
\text { menteri, gajah, } \\
\text { kuda, dan benteng, } \\
\text { namun tidak } \\
\text { terdapat bidak atau } \\
\text { pion di dalamnya. } \\
\text { Dan terdapat } \\
\text { pola zigzag yang } \\
\text { berwarna kuning } \\
\text { keemasan. }\end{array}$ & $\begin{array}{l}\text { Dalam aturan } \\
\text { konvensi permainan } \\
\text { catur merupakan } \\
\text { permainan yang } \\
\text { mengandalkan } \\
\text { strategi dan taktik } \\
\text { untuk meraih suatu } \\
\text { kemenangan. } \\
\text { Dalam meraih suatu } \\
\text { kemenangan tentu } \\
\text { memiliki aturan- } \\
\text { aturan yang berlaku } \\
\text { secara umum. }\end{array}$ & $\begin{array}{l}\text { Simbol dalam karya } \\
\text { ini apabila dikaitkan } \\
\text { dengan judul karya } \\
\text { "cara curang" dan } \\
\text { materi subjek } \\
\text { yakni tentang } \\
\text { kasus "suap" dapat } \\
\text { diartikan bahwa } \\
\text { dengan uang "suap } \\
\text { atau sogok" segala } \\
\text { sesuatu bisa diraih } \\
\text { dan dicapai tanpa } \\
\text { mengikuti aturan- } \\
\text { aturan yang berlaku } \\
\text { secara konvensi. }\end{array}$ \\
\hline
\end{tabular}

Wujud karya seni grafis Reza Sastra Wijaya Secara tekstual terdiri dari papan permainan catur yang dilengkapi dengan buah catur. Adapun buah catur yang ada dalam karya ini terdiri dari raja, menteri, gajah, kuda, dan benteng, namun tidak terdapat bidak atau pion di dalamnya. Dalam aturan konvensi permainan catur merupakan permainan yang mengandalkan strategi dan taktik untuk meraih suatu kemenangan. Dalam meraih suatu kemenangan tentu memiliki aturan-aturan yang berlaku secara umum. Dalam permainan catur gerak dan langkah setiap buah catur memiliki aturan yang berlaku secara konvensi. Gerak dan langkah raja bebas ke arah mana saja baik ke depan, belakang, diagonal, ke kiri dan ke kanan. Namun demikian, raja hanya bisa melangkah sebanyak satu kotak saja, di samping itu raja merupakan kunci permainan, jika raja mati maka permainan selesai. Menteri dalam permainan catur memiliki ruang gerak yang pleksibel yakni bisa bergerak ke semua arah, akan tetapi tidak bisa melompati bidak lain. Dengan pergerakannya yang pleksibel menjadikan menteri dalam permainan catur sebagai daya gedor untuk mengalahkan musuh. Gerak dan langkah gajah juga memiliki aturan secara konvensional yakni hanya bisa melangkah secara diagonal, tetapi tidak bisa melangkahi bidak catur lainnya. Gerak kuda hanya bisa bergerak dengan pola huruf L. yakni dua kotak ke depan dan satu kotak ke samping, akan tetapi gerak kuda bisa melangkahi bidak lain. Sedangkan benteng memiliki peranan penting sebagai pelindung dan juga sebagai penyerang. Secara konvensional gerak dan langkah benteng hanya bisa berjalan lurus ke depan, bawah, ke kiri dan ke kanan, akan tetapi tidak bisa melangkahi bidak yang lain.

Papan permainan catur yang ada di dalam karya ini secara kausal merupakan suatu wilayah kekuasaan. Dalam sistem perperangan kolosal peranan raja, menteri, gajah, kuda, dan benteng merupakan elemen penting dalam meraih kemenangan, dalam permainan catur juga demikian buah catur yang terdapat di dalam karya ini memiliki peranan penting sebagai panglima tertinggi dalam sebuah pertempuran. Pola zigzag merupakan sebuah pola yang tidak beraturan, sedangkan warna kuning keemasan merupakan simbol dari kejayaan, kemenangan dan kegemilangan. Di dalam pola zigzag yang berwarna kuning keemasan dalam karya ini yang di dalamnya juga terdapat buah catur gajah yang sedang memegang senjata pedang seolah-olah ingin membunuh raja dengan cara yang curang. Pesan simbolik yang ingin disampaikan melalui pola zigzag yang berwarna kuning keemasan dengan visual bidak gajah yang membawa pedang dan raja yang berwarna merah dapat diartikan sebagai sebuah alarm bahwa masih banyak ditemukan kasus suap yang terjadi di negeri ini untuk meraih tujuan mereka, khususnya bagi para kaum elit atau para penguasa. Pesan simbolik ini juga ditandai dengan tidak adanya bidak atau pion yang ada di dalam karya ini. Gumpalan awan yang tebal menyelimuti langit akan memberikan suasana mencekam akan terjadinya suatu badai hujan yang lebat. Secara konvensi dapat dikatakan gumpalan awan yang tebal menyelimuti langit, akan membuat orang merasa ketakutan. Begitu juga halnya dengan kasus suap yang terjadi di negeri ini, membuat rakyat jelata merasa ketakutan karena para kaum elit dan pengauasa di negeri ini bisa meraih kemenangan dengan cara apapun, apalagi yang berkaitan dengan persoalan hukum dan keadilan. 
Secara kontekstual, korelasi sistem tanda yang terdapat di dalam karya ini dengan judul karya dan materi subjek atau gagasan pokok yakni tentang kasus "suap" dapat diartikan bahwa dengan uang "suap atau sogok" segala sesuatu bisa diraih dan dicapai tanpa mengikuti aturan-aturan yang berlaku secara konvensi. Seperti yang telah di jelaskan sebelumnya bahwa tanda memiliki arti dan makna berdasarkan kapasitas di mana tanda tersebut dilahirkan, ditempatkan dan digunakan sesuai dengan latar belakang budaya yang beragam. Dalam beberapa kasus yang terjadi di negeri ini sering kali ditemukan kasus suap, mulai dari pemilihan umum yang banyak menerapkan sistem money politik. Dalam kasus hukum juga demikian, banyak penegak hukum di negeri ini yang terlibat dalam kasus suap, bagi para penguasa hukum bisa diperjual belikan. Oleh sebab itu, ada istilah yang menyebutkan bahwa hukum di Indonesia " tajam ke bawah dan tumpul ke atas". Istilah ini memiliki arti bahwa keadilan di negeri ini lebih tajam menghukum masyarakat menengah ke bawah. Pernyataan ini dapat dilihat dari sistem penegakan hukum di negeri ini yang mana ketika seseorang kalah dalam suatu pengadilan negeri tingkat kabupaten misalnya, maka mereka bisa mengajukan banding pada tingkat provinsi, dan seterusnya. Sudah menjadi ketentuan dalam pengajuan banding ini membutuhkan uang pelicin agar proses banding yang diajukan bisa dilaksanakan. Bagi rakyat jelata yang tidak memiliki uang tentu keadilan tidak bisa ditegakkan secar adil. Para penguasa dalam karya ini ditandai dengan buah catur yang terdiri dari raja, menteri, gajah, kuda dan benteng, namun tidak ada bidak atau pion di dalamnya. Dengan kekuasaan, mereka bisa sewenang-wenang dalam mencapai ambisi dan tujuan mereka. Bila dilihat secara kontekstual, dalam meraih suatu kemenangan tentu memiliki suatu aturan yang harus diikuti dan dipatuhi, akan tetapi hal itu tidak berlaku bagi mereka yang memiliki kekuasaan.

\section{KESIMPULAN}

Wujud sebuah karya seni bukan sekedar persoalan menyusun elemen-elemen rupa berdasarkan prinsip penyusunan, akan tetapi persoalan lain yang jauh lebih penting adalah bagaimana tanda berupa pesan simbolik yang ingin disampaikan siseniman melalui karyanya. Struktur tanda yang ada dalam karya seni grafis ini mencoba melahirkan diskursus baru dengan mengaitkan satu objek dengan objek lainnya. Ekspresi yang dituangkan ke dalam medium seni merupakan suatu kebaruan dan belum pernah terumuskan sama sekali melalui kode-kode yang ada. Dengan segala kemampuannya siseniman melahirkan tanda-tanda baru di dalam karyanya dengan cara mengaitkan suatu objek dengan objek lainnya berdasarkan suatu aturan yang berlaku secara umum (konvensi). Melalui penelitian ini dapat disimpulkan bahwa pesan yang ingin disampaikan siseniman melalui karya seni grafis yang berjudul "cara curang" dengan subjek mater yakni kasus "suap" merupakan representasi dari suatu realitas yang diamati, melalui stimulus maka lahirlah suatu karya seni. Pesan simbolik yang ingin disampaikan dalam karya ini adalah bahwa dengan uang "suap atau sogok" segala sesuatu bisa diraih dan dicapai tanpa mengikuti aturan-aturan yang berlaku secara konvensi. Salah satu kasus adalah keadilan, dengan uang "suap" keadilan di negeri ini bisa diperjual belikan.

Tampilan visual dan pesan simbolik dalam karya ini cukup menarik untuk ditelusuri dan dikembangkan dalam penelitian lanjutan dengan pendekatan teori semiotika lainnya seperti Sassure, Roland Barthes, Umberto Eco, dan Fiske. Di samping itu, juga bisa menggunakan pendekatan yang berbeda seperti pendekatan estetika, sosiologi, komunikasi, dan lainnya. Dengan pendekatan multi disiplin ilmu, akan memperkaya khazanah kesenian khususnya seni rupa dan desain dan mempermudah masyarakat luas dalam mebaca suatu tanda berupa pesan simbolik yang ada di dalam karya seni.

\section{DAFTAR PUSTAKA}

[1]. Patriansyah M. Analisis Semiotika Charles Sanders Peirce Karya Patung Rajudin Berjudul Manyeso Diri. Ekspresi Seni. 2014;16(2):240.

[2]. Marianto MD. Menempa Quanta Mengurai Seni. pertama. Yogyakarta: Yogyakarta : ISI Yogyakarta; 2011.

[3]. Pilliang AY. Hipersemiotika, Tafsir Cultural Studies Atas Matinya Makna. Bandung: Jalasutra : Bandung; 2003.

[4]. Danesi M. Pesan, Tanda, dan Makna: Buku Teks Dasar Mengenai Semiotika dan Teori Komunikasi. Yogyakarta: Yogyakarta: Jalasutra.; 2010.

[5]. Budiman K. Semiotika Visual, Konsep, Isu, dan Problem Ikonisitas. Pertama. Yogyakarta: Yogyakarta : Jalasutra; 2011. (Book)

[6]. Hoed BH. Semiotik dan Dinamika Sosial Budaya. ketiga. Depok: Depok : Komunitas Bambu; 2014. (Book) 
[7]. Sumardjo J. Filsafat Seni. Bandung: Bandung : ITB Bandung; 2000.

[8]. Sudarmaji. Dasar-dasar Kritik Seni Rupa. Jakarta.: Balai Seni Rupa Jakarta: Jakarta; 1979.

[9]. Bahri NF. Analisis Semiotika Roland Barthes pada Masjid Keraton Buton di Kota Baubau, Sulawesi Tenggara. J Rupa. 2020;4(2):121.

[10]. Hidayat R. Analisis Semiotika Makna Motivasi Pada Lirik Lagu “Laskar Pelangi” Karya Nidji. eJournal IImu Komun [Internet]. 2014;2(1):243-58. Available from: http://www.fisip-unmul.ac.id 